\title{
Monoclonal antibodies to human IgM
}

Agus Sjahrurachman, Agustin Indrawati, Betty Ernawati, Fera Ibrahim, Mardiastuti

\begin{abstract}
Abstrak
Tersedianya antibodi terhadap IgM manusia penting dalam mengembangkan berbagai format uji diagnostik untuk penyakit infeksi yang notabene saat ini masih prevalen di Indonesia. Dalam penelitian ini dijajagi pembuatan antibodi monoklonal terhadap IgM manusia dengan jalan memfusikan sel limfosit kebal dengan sel mieloma. Setelah melalui beberapa kali proses rekloning didapat beberapa klon penghasil antibodi anti IgM manusia yang tidak reaktif terhadap IgG, IgA ataupun serum manusia yang telah dihilangkan IgG dan IgA-nya. Dari hasil penentuan subklasnya, antibodi anti IgM manusia tersebut termasuk dalam subklas IgG2a.
\end{abstract}

\begin{abstract}
Availability of specific antihuman IgM antibodies is very important for developing diagnostic kits for infectious diseases that are highly prevalent in Indonesia. In line with such idea, an attempt to construct hybridoma cells producing antihuman IgM antibodies is done by fusing NS-1 myeloma cell line with immunized mouse spleen cells. Hybridomas producing anti human IgM antibodies have been obtained and antibodies produced by several exhaustedly cloned hybridomas has been characterized. Those antibodies are not reactive to human IgG, IgA nor IgG and IgA-deprived human serum and belong to IgG2a subclass.
\end{abstract}

Keywords: Diagnostic, Mouse hybridoma, Monoclonal antibody, antihuman IgM

Heterologous anti sera or polyclonal antibodies were popular up to the mid 1980. Those anti sera had been used for diagnostic, therapeutic as well as prophylactic purposes. However, since the introduction of hybridoma technology by Kohler and Milstein many of them have been replaced by monoclonal antibodies. ${ }^{2,3,4,5,6,7,8,9}$ In fact, at present numerous monoclonal antibodies to etiologic agent of infectious diseases has been used or potentially used for diagnostic purposes. ${ }^{4,5,6,7}$

On the other hand, it is well known that in any infection an antibody response is induced by the etiologic agents of infectious diseases. In primary infection, IgM antibodies is first synthesized followed by IgG antibodies. Following recovery of the infection, titer of IgM antibodies will then decrease and may not be able to be detected after several months. In secondary infection, serum titer of IgM will also increase though not as much as IgG. ${ }^{10,11}$ Therefore, detection of specific IgM antibodies would be very helpful for confirming diagnosis. In accord with such idea, we conduct an attempt to construct murine monoclonal antibodies to human IgM.

Department of Microbiology Faculty of Medicine University of Indonesia, Jakarta, Indonesia

\section{METHODS}

\section{Mice immunization}

A group of five mice is immunized with human IgM preparation having $80 \%$ purity. First immunization is done using 50-100 $\mu \mathrm{g}$ human IgM preparation in 0.1$0.25 \mathrm{ml}$ complete Freund Ajuvant given subcutaneously. Four weeks later, $50 \mu \mathrm{g}$ human IgM preparation in incomplete Freund Ajuvant is injected subcutaneously. On week five, $25 \mu \mathrm{g}$ human IgM in phosphate buffer saline is intraperitoneally injected. Mice showing good immune response are re-immunized on three consecutive days with $25 \mu \mathrm{g}$ human IgM in phosphate buffer saline by intra peritoneal route.

\section{Cells}

NS1 myeloma cells is maintained in RPMI 1640 media supplemented with $10 \%$ fetal bovine serum in $5 \%$ $\mathrm{CO}_{2}$ atmosphere. The cells is passaged in media containing azaguanine twice before being used for fusion. Viability of the cells prior to fusion is greater than $85 \%$.

Spleen of mouse showing high immune response is taken four days after the last immunization. Splenocytes is purified by lysing red blood cells with lysing solution containing ammonium chloride. 
shown in table 5 and typical example of Elisa employing various amount of antigen is shown on fig 1 .

Table 3. Results of Elisa on hybridoma culture fluid containing high titer of antihuman IgM antibodies expressed as Optical Density Value (OD)

\begin{tabular}{rccccr}
\hline No & Clone's code & OD & No & Clone's code & OD \\
\hline 1 & A7C10 & $>2.00$ & 18 & D10E3 & 1.67 \\
2 & D8C10 & $>2.00$ & 19 & C7C7 & 1.65 \\
3 & F3C10 & $>2.00$ & 20 & C10C7 & 1.63 \\
4 & A4C10 & $>2.00$ & 21 & G1E3 & 1.65 \\
5 & C4C10 & $>2.00$ & 22 & B5C7 & 1.65 \\
6 & D9C10 & $>2.00$ & 23 & H10E3 & 1.78 \\
7 & E1C8 & 1.69 & 24 & F2E3 & $>2.00$ \\
8 & D8C8 & 1.74 & 25 & G1E3 & $>2.00$ \\
9 & A8C8 & 1.72 & 26 & F5E3 & $>2.00$ \\
10 & C5C8 & 1.71 & 27 & H11E3 & 1.70 \\
11 & G2C8 & 1.67 & 28 & D12E3 & 1.75 \\
12 & H3C8 & 1.71 & 29 & G10E3 & 1.62 \\
13 & G12C8 & 1.75 & 30 & H12D9 & 1.61 \\
14 & G8C8 & 1.69 & 31 & E8D9 & 1.49 \\
15 & A7C7 & 1.71 & 32 & A1D9 & 1.50 \\
16 & C8C7 & 1.72 & 33 & Positive sera & $>2.00$ \\
17 & D12C7 & 1.78 & 34 & Negative sera & 0.34 \\
\hline
\end{tabular}

Table 4. Results of direct Elisa test employing I $\mu \mathrm{g}$ coated antigens expressed as $\mathrm{OD}$.

\begin{tabular}{lcllc}
\hline & \multicolumn{4}{c}{ Coated antigen } \\
\cline { 2 - 5 } Clone & IgM & IgG & IgA & Igs deprived-serum \\
\hline A7C10 & $>2.00$ & 1.16 & 1.38 & -0.02 \\
D8C10 & $>2.00$ & 1.21 & 1.37 & -0.02 \\
A7C7 & 1.71 & 1.19 & 1.24 & 0.00 \\
E1C8 & 1.69 & 1.27 & 1.33 & 0.00 \\
G2C8 & 1.67 & 1.35 & 1.39 & 0.00 \\
A1D9 & 1.50 & 1.21 & 1.27 & 0.00 \\
F2E3 & $>2.00$ & 1.21 & 1.32 & 0.01 \\
F5E3 & $>2.00$ & 1.21 & 1.27 & 0.00 \\
\hline
\end{tabular}

Isotyping of antibodies was done using commercially available isotyping Elisa kit employing goat-anti mouse IgG1, IgG2a, IgG2b, IgG3,IgM and IgA. Antibodies produced by six clones, i.e A7C10, D8C10, $\mathrm{A} 7 \mathrm{C} 7, \mathrm{E} 1 \mathrm{C} 8, \mathrm{G} 2 \mathrm{C} 8$ and A1D9 belong to IgG2a subclass.

Table 5. Results of competitive Elisa expressed as OD

\begin{tabular}{|c|c|c|c|c|c|c|c|c|c|c|}
\hline & \multicolumn{10}{|c|}{ Type and amount $(\mu g)$ of competitor } \\
\hline & \multicolumn{5}{|c|}{ IgG } & \multicolumn{5}{|c|}{ IgA } \\
\hline Clone & 0 & 0.001 & 0.01 & 0.1 & 1.0 & 0 & 0.001 & 0.01 & 0.1 & 1.0 \\
\hline $\mathrm{A} 7 \mathrm{C} 10$ & 1.03 & 1.02 & 1.03 & 1.03 & 1.02 & 1.02 & 1.02 & 1.02 & 1.02 & 1.02 \\
\hline $\mathrm{D} 8 \mathrm{C} 10$ & 1.04 & 1.03 & 1.03 & 1.04 & 1.03 & 1.02 & 1.03 & 1.03 & 1.03 & 1.03 \\
\hline A7C7 & 0.84 & 0.84 & 0.84 & 0.84 & 0.84 & 0.84 & 0.83 & 0.84 & 0.83 & 0.83 \\
\hline $\mathrm{E} I \mathrm{C} 8$ & 0.98 & 0.98 & 0.98 & 0.98 & 0.98 & 0.98 & 0.98 & 0.98 & 0.98 & 0.98 \\
\hline $\mathrm{G} 2 \mathrm{C} 8$ & 0.80 & 0.86 & 0.88 & 0.83 & 0.80 & 0.79 & 0.73 & 0.75 & 0.75 & 0.78 \\
\hline F5E3 & 0.90 & 1.00 & 1.03 & 0.98 & 0.98 & 0.92 & 0.95 & 0.93 & 1.00 & 0.93 \\
\hline AlD9 & 0.90 & 0.90 & 0.90 & 0.90 & 0.90 & 0.90 & 0.90 & 0.90 & 0.90 & 0.90 \\
\hline F2E3 & 0.96 & 0.96 & 0.96 & 0.96 & 0.96 & 0.96 & 0.96 & 0.96 & 0.96 & 0.96 \\
\hline
\end{tabular}

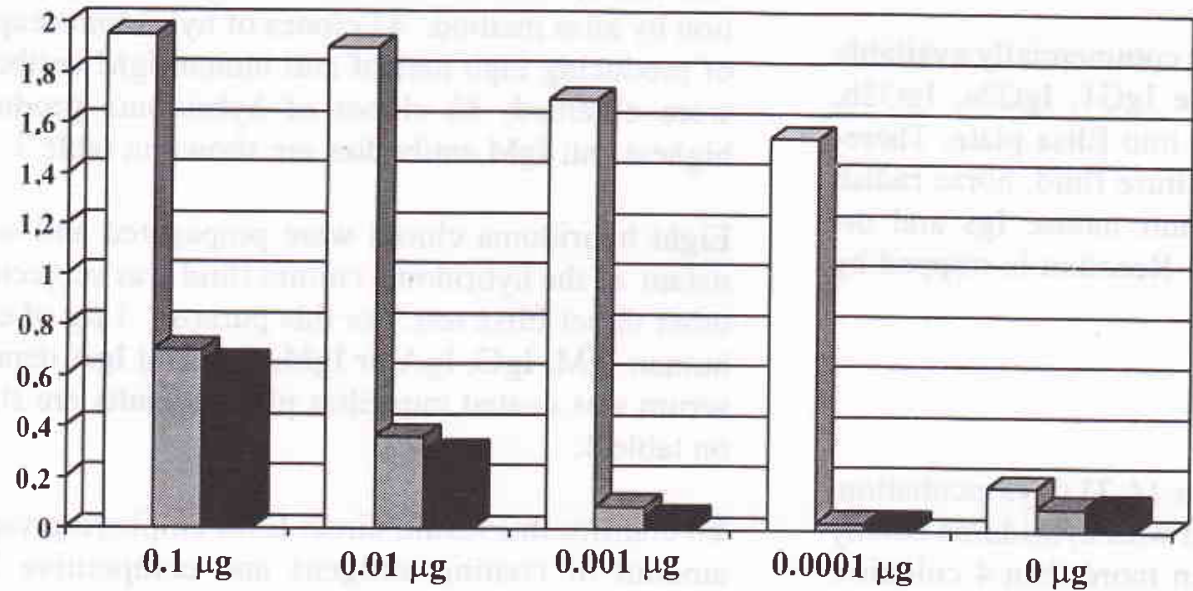

Figure I. Elisa result of $A 7 C 10$ hybridoma clone culture supernatant employing different amount of coated antigen preparations 


\section{DISCUSSION}

Infectious diseases are important health problems because of its high prevalency and high mortality in Indonesia. ${ }^{13}$ Unfortunately however, it is not easy to determine etiologic agent of such diseases in daily medical practices. On the other hand it is known that in any infectious diseases specific IgM antibodies are induced as an early immune response. ${ }^{10,11}$ Capturing specific IgM antibodies therefore could be one among other simple ways to confirm the etiologic agents implying the necessity of continuous supply of anti human IgM antibodies. This need can be addressed by constructing hybridoma producing monoclonal antibodies specific to human IgM.

Hybridoma obtained at present study is constructed by fusing NS-1 myeloma cells and hyper-immunized mouse spleen cells. The result indicated that fusion efficiency of the present study is relatively high as reflected by growth of numerous hybrid cell colonies. It was noticed that on first antibody screening, antibody content as reflected by optical density value of the culture fluid is low. This is not surprising since on the first plating, the hybridomas are still heterogenous.

After exhaustedly cloned, elisa result of culture fluid of eight hybridomas revealed high optical density value approaching those of hyper-immunized sera indicating that such hybridoma produce high titer of antibody. However, when such culture fluid was screened using $1 \mu \mathrm{g}$ of coated Igs the results showed a possibility of cross reaction of the antibodies to human IgM, IgG and IgA. Considering that IgM, IgG and IgA preparations are not pure, such cross reactive pattern may also due to the impurities of the coated Igs. In order to determine the cause of such result, a competitive Elisa and a direct Elisa employing varied amount of coated Igs are conducted. Results indicate that neither IgG nor Ig A compete with IgM. Further reducing coated Igs did not significantly decrease optical density value of $\operatorname{IgM}$, but OD of IgG and IgA were decreased. Therefore it is concluded that the monoclonal antibody obtained is specific to human IgM.

\section{REFERENCES}

1. Artama IW. Antibodi monoklonal dan rekombinan antibodi serta aplikasinya dalam imunoterapi. Fakultas Kedokteran Universitas Gadjah Mada, 1992.

2. Kohler $\mathrm{G}$ and Milstein $\mathrm{C}$. Continuous culture of fused cells secreting antibody of predetermined specificity. Nature 1975; 256: 495-7.

3. Krakauer H. Clinical application of monoclonal antibodies. Eur J Clin Microbiol 1985; 4: 1-9.

4. Yamaura H, Uchiyama T, Terakada N. Production and epidemiological application of monoclonal antibody specific for Salmonella O5 antigen. Kitasato Arch Exp Med 1992; 65: 13-22.

5. Brinker JP and Herman JE. Comparison of three monoclonal antibody-based enzyme immuno assay in clinical specimens. Eur J Clin Microbiol Infect Dis. 1995; 14 314-7.

6. Da Silva AJ, Piuvezam MR, de Moura H. Rapid competitive Elisa using a monoclonal antibody reacting with a $15 \mathrm{kd}$ tegumental antigen of $S$. mansoni for serodiagnosis of schistosomiasis. J Clin Microbiol 1993; 31: 2315-9.

7. Zhang GH, Baek L, Nielsen PE, Buchardt O, Koch C. Sensitive quantitation of endotoxin by enzyme linked immunosorbent assay with monoclonal antibody against limulus peptide C. J Clin Microbiol 1994; 2: 416-22.

8. Sullivan T, Hechemy KE, Harris HL, Rudolfsky UH, Samsonoff WA, Peterson AJ, et al. Monoclonal antibodies to native P39 from B. burgdorferi. J Clin Microbiol 1994; 2 423-9.

9. Fagenberg J, Hjelm AL, Ragnhammar P. Tumor regression in monoclonal antibody-treated patients correlate with the presence of anti-idiotype reactive $\mathrm{T}$ lymphocytes. Cancer Res 1995; 55: 1824-7.

10. Brooks GF, Butel JS, Morse SA (eds). Jawetz, Mclnick, Adelberg's. Medical microbiology. $21^{\text {st }}$ ed. Lange Med Publ New Jersey 1998. p. 124-6.

11. Berkow R. The Merck manual of diagnosis and therapy. $15^{\text {th }}$ ed. Merck-Sharp and Dohme New Jersey 1989. p. 257-71.

12. Zola H, Brooks D. Techniques for the production of monoclonal hybridoma antibodies. In: Hurrell JGR (ed). Hybridoma antibodies: techniques and application. CRC Press Inc. Florida 1982. p. 33-6.

13. Anonymous. Studi morbiditas disabilitas di Jawa dan Bali. Badan Penelitian dan Pengembangan Kesehatan Departemen Kesehatan Republik Indonesia, 1996. 


\title{
Genetic factors associated with susceptibility to obesity
}

\author{
Jeanne Adiwinata Pawitan
}

\begin{abstract}
Abstrak
Tinjauan pustaka ini membicarakan berbagai faktor genetik dan protein yang berhubungan dengan obesitas. Tiga mekanisme yang mendasari obesitas adalah: peningkatan relatif masukan energi, penurunan relatif penggunaan energi, dan kecenderungan penyimpanan kalori dalam bentuk lemak. Kelainan genetik dapat mendasari salah satu dari ketiga mekanisme tadi, baik sendiri ataupun bersamaan. Banyak faktor genetik yang berhubungan dengan kecenderungan mengalami obesitas, yaitu: peningkatan ekspresi protein 'agouti' atau protein 'serupa agouti'; defisiensi leptin, defisiensi atau mutasi reseptor leptin, gangguan pada jalur karboksipeptidase, mutasi 'tubby', peningkatan ekspresi GLUT4 transporter glukosa, mutasi reseptor serotonin 5-HT2C, dan gangguan pada CCK atau reseptor CCK-A.
\end{abstract}

\begin{abstract}
This review discusses the various genetic factors and gene products (proteins) related to obesity. The three fundamental mechanisms underlying obesity are: relative increase in energy intake; relative decrease in energy expenditure; and preferential partitioning of ingested calories to fat storage. Gene defects can be related to any one of these mechanisms, either alone or together. Many genetic factors are associated with susceptibility to obesity, i.e. over expression in agouti signaling protein or agouti related proteins; leptin deficiency, leptin receptor mutation or deficiency, abnormality in carboxypeptidase pathway, tubby mutation, over-expression of GLUT4 glucose transporter, serotonin 5-HT2C receptor mutation, and defect in CCK or CCK-A receptor.
\end{abstract}

Keywords: agouti, leptin, leptin receptor, carboxypeptidase, tubby, GLUT4 glucose transporter, serotonin 5-HT2C receptor, CCK, CCK-A receptor

The three fundamental mechanisms underlying obesity are: 1) relative increase in energy intake; 2 ) relative decrease in energy expenditure; and 3) preferential partitioning of ingested calories to fat storage. ${ }^{1}$ Gene defects can be related to any one of these mechanisms, either alone or together. Experiments using transgenic animals showed that obesity was related to various genetic factors, either single or multiple. This review discusses the various genetic factors and gene products (proteins) related to obesity i.e. the agouti signaling protein (ASP), OB protein/leptin (lep), OB receptor/leptin receptor (Lepr), and many other factors.

\section{Agouti signaling protein (ASP)}

In mouse, ASP is coded by the agouti locus. ASP is a 131-amino acid peptide with a 22-amino acid signal peptide, a central basic region and a cysteine-rich Cterminus. It is normally produced only in the hair folicle and testes.

Department of Histology, Faculty of Medicine, University of Indonesia, Jakarta, Indonesia
A mouse with autosomal dominant agouti gene defect is characterized by obesity, hyperphagia, hyperinsulinemia, and hypercorticosteronism. The defect in the gene encoding ASP is located in the noncoding region that control the promoter, resulting in overexpression of a structurally unaltered ASP. Overexpression of ASP occurs in usual and ectopic (e.g. brain) sites. ${ }^{1}$ In brain, ASP competes with high affinity against melanocyte-stimulating hormon (MSH) at one type of MSH receptor (melanocortin receptor, MC4R). ${ }^{1,2}$ Fan et al (1977) showed that melanocortic neurons exert a tonic inhibition of feeding behaviour. ${ }^{3}$ Thus, it appears likely that some of the obesityproducing efeects of ASP expression in the brain may be due to its interference with signal generation by MSH at MC4R, a signal which normally act to suppress food intake. Furthermore, ASP also appears to induce lipogenesis by enhancing insulin sensitivity, ${ }^{1}$ due to the increasing intracellular $\mathrm{Ca} 2+[\mathrm{Ca}+2] \mathrm{i} .{ }^{4-6}$ In addition, recombinant agouti exerts a potent antilipolytic effect in human adipocytes via a $[\mathrm{Ca} 2+] \mathrm{i}$ dependent mechanism. ${ }^{4}$

Kesterson et al (1997) showed that expression of neuropeptide Y (NPY), a potent stimulator of food 